\title{
ORPHANS OF LIVING PARENTS: A COMPARATIVE LEGAL AND SOCIOLOGICAL VIEW
}

\author{
RAPHAEL LEMKIN*
}

\section{INTRODUCTORY REMARKS}

Divorce occurring in a family in which minor children are involved brings to light an area of deep human conflicts. On the one hand there is a clash between the interests of the controlling parents, at least one of whom desires to liquidate the marriage. On the other hand, the children normally desire to preserve their home and live with both parents. In societies in which the percentage of divorce has increased in recent times a tendency may be noticed to subordinate the normal interest of the children to the personal wishes of the spouses. Such a tendency is an example of the destruction of the happiness and security of the weaker members of the society by the stronger. More specifically it means that the future generation is not sufficiently protected in divorce, despite the growing interest in the welfare of the child in other fields of social policy throughout the world.

The situation may be remedied by the recognition of the acute crises that the presence of children creates in a divorce, by developing special procedures and institutions which would enable those working with the problem to obtain a better understanding of the details of each case and a more efficient protection of the child, without disregarding the interests of the parents, if they prove to deserve really serious consideration.

Persons who come in contact with divorce cases, such as the lawyer and the social worker, should come closer in their thinking about a common task and should unite their efforts if they are to do their best work.

- Magister Juris, Doctor Juris, I926, University of Jan Casimir. Lvov, Poland. Member of the Polish Bar, and once Public Prosecutor in charge of divorce cases in Warsaw. Head Consultant, Board of Eco. nomic Warfare and Foreign Economic Administration, Washington, D. C., 1942. Member of the Faculty of Political and Social Science of the Free University of Warsaw, since 193r; University of Stockholm, I940; Lecturer, Duke University Law School, I941-r942. Lecturer, War Department School of Military Government, Charlottesville, Virginia, summer 1942. Member of International Committce for the Unification of Penal Codes at the League of Nations (Fifth Committee), 1931-1939; delegate of Poland at the International Juridical Conferences in Brussels, Paris, Madrid, Copenhagen, Rome, Palermo, Prague, Cairo, Amsterdam, The Hague, and Budapest. Author, in Polish: The Poush Penal Code (with Justices Jamontt and Rappaport of the Polish Supreme Court, Warsaw, I932); The Judge Confronted gy Modern Criminal Law and Crininology (Warsaw, 1933); Amnesty (Warsaw, 1935); Financial, Law (Warsaw, I937); The Russian Penaz Code (Warsaw, I928); The Italian Penal Code (Warsaw, 1929); in French: The Regulation of International Payments (Paris, 1939); in Swedish: Exchange Control and Clearing (University of Stockholm lectures, I940-194I); in English: Axis Rule in Occupied Europe (Washingon, 1944). Author of monographs, papers and articles on the laws of the Far East, Africa, Europe and Latin-American countries; and also on international law and international finance in Polish, French, English, Swedish, Italian and German.

Acknowledgment is hereby made to Philip Nochlin, student of Oberlin College, for assistance in the preparation of this article. 
It may not be premature in the year 1944 to envisage new methods of action. This present war has already increased and the postwar period may even increase further the number of divorces. Some of this domestic unrest is due to the fact that many marriages were hastily entered into and long absences of the husband-soldier may alienate the affections of the spouses.

Apart from society's warm interest in the integrity of the family, we must not overlook the dangers to democracy in disregarding problems arising out of the instability of the home, since anti-democratic elements may use the resulting dissatisfactions for their own political purposes. We can see this in the professed protection of the home and the family by Mussolini, Hitler, Franco and more recently, Petain.

\section{Comparative Bastc Conceptions}

It is essential for the understanding of the problem of children of divorced parents to make a brief investigation into the ideologies behind family life and divorce. Some particular ideology affects directly the existence of each family and influences indirectly the fate of its children. In a broader sense the status of the children in every country depends upon the basic ideological conception to which that society adheres. One may distinguish the following basic conceptions, of family relationships affecting children.

\section{The Clan Conception}

In several countries in the Far East ${ }^{1}$ and to a certain extent in Northern Africa, family life is distinguished by a close interconnection between people related by blood to one another and living mostly but not necessarily exclusively in one household, headed by the eldest of the group. Such a group is bound by ties both sentimental and economic. There is an obligation of love and support and, of course, of respect to the head of the group who provides leadership. This clan conception is important to the study of our problem. In a society based on the clan the dissolution of a smaller family unit through divorce does not affect so much the fate of its children. They still remain in the framework of the larger clan. The clan, as a whole, takes care of those children whose parents are divorced. Thus the shock of divorce is absorbed by the care given by the kin. ${ }^{2}$ To a certain extent a clan conception has survived in the family life of the American Negro who brought it over with him from Africa. The Negroes in the South often live in large family groups. $^{3}$ In a clan the children of divorced persons and even the illegitimate children are taken care of by all relatives. Because of this solidarity the breaking up of the Negro family either by divorce or desertion does not so seriously affect the fate of the children involved. ${ }^{4}$

\footnotetext{
${ }^{1}$ Mare van der Valk, OutLine of Modern Chinese Family Law (1939) esp. 14-24, 158-161.

${ }^{2}$ Agriculture with its inherent stability of residence has largely contributed to the maintenance of the clan institution in countries which adhere to it.

- Herskovits, Myth of the Negro Past (i94I) 173 ff.

'It seems that this type of clan solidarity has been strengthened during the period of slavery. It often occurred that the father was sold at one occasion and the mother at another, so that the relatives bad to take care of the children.
} 


\section{The Roman Catholic Conception}

The conception of the family in the Roman Catholic Church was developed from the point of view of the universal, eternal, and supernatural.5 The sacrament of marriage can in the strict interpretation of official dogma be dissolved only by the death of one of the spouses. Furthermore the family is considered permanent and holy inasmuch as it cooperates with God in the creation of children and in the task of instructing them for admission to His kingdom. Indeed the Roman Catholic conception implies that the family, not the individual, is the basis of civil society; the welfare of the individual remains, however, the end of both the family and the State. Thus the Roman Catholic Church acts as a protector of the family and the children. It has ever opposed divorce except for one possibility in which nonChristian marriage is dissolved by absolute divorce in favor of the Faith; but its importance is now theological rather than social. Separation from bed and board is admitted, as a solution for some types of domestic discord.

The Roman Catholic conception has influenced legislation in those non-Catholic countries which have introduced divorce, especially in formulating the issues on the basis of guilt, whereby divorce is awarded to the legally innocent.

\section{The Racial and State Conception of Family Life}

National Socialism considers the family, first of all, as an institution furthering the idea of racialism and promoting the interests of the folkish community and of the German State, through procreation of children. Hitler said: "Marriage cannot be an end in itself. Instead, it must serve one higher end of multiplying and preserving the race. That alone is its meaning and function." ${ }^{8}$ The family is protected as a unit as long as it serves these purposes; and as long as all members of the family are living according to the principles of National Socialism. Divorces and custody of children are administered accordingly. ${ }^{7}$ The decisions of German courts in this respect are illuminating. In one case the Reichsgericht held that the wife of a member of the National Socialist Party had committed a serious marital offense by continuing her social intercourse with a woman who had been punished for having an affair with a Jewish doctor. ${ }^{8}$ In other cases the court deprived a divorcee of the custody of her two children because she intended to place them in Catholic convent schools; and it deprived even a married couple of the custody of their children on the grounds that the parents were adherents of the Bible Students Association and forbade the children to join the Hitler Youth.

\footnotetext{
${ }_{5}^{5}$ Catholic Encrclopedia (igog) 54-68, 782-84.

- Hitler, Mein KampF (277th German ed. 1937) 275.

${ }^{7}$ For the text of the Divorce Law of the Greater German Reich enacted as a unified text at the occasion of the annexation of Austria, see Law of July 6, I938 (1938) Reichsgesetzilatr 807.

${ }^{8}$ Reichsgericht (Supreme Court of the Reich) Jan. 7, 1937, 29 Warneyer II9, No. 53, as quoted from Schoch, Divorce Law and Practice Under National Socialism in Naxi Germany (1943) 28 IowA L. REv. 225, 230.

' See Schoch, supra note 8, at 253, n. 178 .
} 


\section{The Contractual-Hedonistic Conception of Family Life}

According to this conception a man is free to seek his happiness as he will, especially in his private relations. Marriage is essentially a contract, which can be dissolved if it does not serve the purpose of making the spouses happy. Practically, the grounds of divorce listed in the law are less important than the desire and readiness of the court to dissolve an unhappy marriage. Great weight is given to individual wishes because of the lack of public disapproval of easy divorce; the desire of the parent to dissolve the marriage is superior to the interest, and even the desire, of the children to have the marriage maintained. Consequently when the parents decide to secure a divorce, the fate of the children is left in many instances to the legalistic intricacies and the inevitable unpredictability of maintenance orders. The contractual-hedonistic conception seems to prevail within certain groups in France, United States, and in the Scandinavian countries, but a reaction against such attitudes is being felt more and more strongly in favor of the child. The White House Conference on Children in a Democracy on January I9, I940 has expressed the following view: Home and family are the first condition of life for the child. They are first in importance for his growth, development, and education. ${ }^{10}$

\section{The Russian Free Love Conception and Its Decline}

The "free love" conception, pervading Russian family life after the I9I7 revolution, found its expression in the lack of formalities in entering as well as dissolving marriage. According to Soviet family law the parties might enter marriage or dissolve it merely by registration. ${ }^{11}$ But neither party was obliged to observe even these slight formalities. ${ }^{12}$ Marriage was based upon free love and factual cohabitation in a family-like manner. The marriage was dissolved through the unilateral decision of one party. In such a system little difference could exist between the status of legitimate and illegitimate children. The State took care, in many cases, of all the children. By introducing such a system of family life the Soviet legislator wanted to give unlimited freedom to the individual in his family relations. Especially he was anxious to establish equality between the sexes. Lenin wrote: "No vestige remained in Soviet Law from the inequality between man and woman."13

This situation has been radically changed during the present war. A decree of July 16 , 1944, introduced a marked protection of family life. ${ }^{14}$ The most striking innovation consists in precluding the mother from establishing fatherhood of her child through court action, if the marriage was not registered. Divorce is no longer left to the unilateral decision of one party, but can be granted only by court order

${ }^{10}$ Children in a Densocracy (General Report adopted by the White House Conference on Children in a Democracy, Jan. 19,1940$)$ 10.

${ }^{11}$ See Chao, Code of Laws on Marriage, Family and Guardianship of the Russian Socialist Federated Soviet Republic (London, 1936), esp. arts. I, 3, 12, I8.

${ }^{12} 3$ Enctclopaedia of State and LAw (title transliterated, Moskva I925-r927) 630.

18 lbid.

14 Official Gazette of the Suprexe Soviet of U.S.S.R. No. 37, July 16, r944 (title transliterated). 
after hearing both parties and the witnesses. Granting the divorce is within the discretion of the court. The court must endeavor to reconcile the parties in special proceedings, to which witnesses are summoned. Moreover, divorces are discouraged by exceedingly high court costs.

The above-mentioned decree of 1944 also promotes increase of the birth rate by taxing childless citizens, by granting family allowances for additional children and even by awarding medals and distinctions of different degrees to mothers who have five or more children. The highest degree of the distinction "The Mother's Honor" is granted to a mother who has nine children. ${ }^{15}$

Hence for demographic and other reasons the free-love conception of Soviet family life has been in principle abolished.

\section{General Considerations Concerning the Child and Divorce}

In ancient times and in feudal society the child was completely subordinated to parental power. In ancient Rome the father's authority (patria potestas) was so great as to include the control over the life and death of his child (ius vitae ac necis). In the face of this overwhelming power of the parents, society and the State could not express too much concern about the child as long as he was within the limits of the family. But nowadays, while the respect for the family has in no way diminished, the interest of society in the child has grown. He is no longer treated as a chattel but is to be considered rather as a future citizen. Numerous reform measures by private organizations and governments both on a national and international scale have been promoted since the second half of the last century on behalf of the child. Health, education, recreation, morality, even the type of movies the child should see, financial aid and support by the State-all have been made the concern not only of one social group but of all the world. By way of illustration, one may cite the splendid work done in this field by the Child Welfare Bureau of the League of Nations, by the Pan-American Congress, and by national agencies of various countries such as in particular the Children's Bureau of the Department of Labor in the United States and the Social Security Board in Sweden.

In view of this concentrated national and international interest to help the child by all available means one wonders why relatively so little has been accomplished in preserving the most precious safeguard of the child welfare-namely-the family? There is not enough evidence in the legislation of various countries of special treatment for the social problems of children of divorced parents. There is even less evidence of the existence of an adequate and efficient machinery for enforcement of the legal rights of the child whose parents have been divorced.

\section{The Importance of the Family to the Child}

Within the structure of modern society the family unit is the basic organization in which children are raised and educated. The psychological and moral solidarity

${ }^{25}$ Ibid. 
of the family, the respect which children have for the moral standards of the parents, the confidence and security which they find in their parents' affection, determine in large measure how well a child can adapt itself to the moral and behavior standards of society. The predisposition to be moral, as well as native intelligence, develops through education within the family. The child is a talented imitator and responds readily to suggestions. It is especially important that suggestions be made to him in the field of morals. The family is the main source of moral education and upon its social health and normalcy depends a great part of the ethical culture and social stability of the future generation. For these reasons and many others society is vitally interested in preserving the family as a basic institution for education of children.

\section{The Broken Home and Its Implication for the Child}

By broken home we mean the disruption of the family through involuntary causes (death) and voluntary causes (divorce-desertion). Most of the studies on children do not distinguish divorce as the single disturbing factor. It is not easy therefore to establish how many of the disasters caused to children are due specifically to divorce.

In some cases divorce does rescue the child from the bad environment pressures of a disintegrating family in which he may be exposed to the deteriorating influence of a vicious parent or to a constant demoralization of his feelings by witnessing quarrels and conflicts between the parents. Sometimes, although exceptionally, the child of divorced parents benefits because he may become more serious and prematurely sensitive to the responsibilities of life, with an increased affection toward the custodial parent. He may, even, grow morally within the framework of the remainder of a disrupted family.

However, speaking in terms of average situations and average children, we recognize that divorce is detrimental to the life of the child. The first shock comes to his emotions when he loses a beloved parent. His contacts with other children who have parents may create in him a sense of inferiority. He has only one parent while his playmates have two. Moreover the constant contact with a parent of only one sex deprives the child of those necessary character-forming influences which the parent of the other sex can give. Accordingly, a son may become too effeminate and a daughter too masculine in attitudes and behavior. Mowrer thinks that divorce leads a child to take a critical attitude toward marriage and that a child of divorced parents tends to enter his own marriage relations "in a highly skeptical frame of mind, only to find in it all that he has feared. Thus divorce is passed on from one generation to the next."16

Case studies with children of broken homes show that such children often possess less intelligence. This is not an intrinsic failing; rather, it tends to develop because

${ }^{10}$ Mowrer, Divorce and Readjustment (x932) I60 ANsals (of the American Academy of Political and Social Science) I91, I96. 
their minds become erratic and disturbed and they find it hard to concentrate. Such children often have difficulties in their school work with mathematics and reading, in comparison with children from normal homes. ${ }^{17}$ In personality tests, made among children of broken homes in comparison with children of normal homes, it appears that children from normal homes generally rate higher. ${ }^{18}$

\section{Divorce and Juvenile Delinquency}

Disintegration of home morals and underprivileged economic conditions are among the most frequent causes of juvenile delinquency. In poor neighborhoods dirt, poverty and insecurity foster a natural desire to escape. If there is inadequate guidance from parents, children tend to take the line of least resistance and to accept the companionship of the street gang. Investigations into juvenile delinquency in the United States show that a very high percentage of juvenile offender cases come from broken homes. In some the figures show that such children represent as much as 53 per cent of the general number of juvenile offenders. ${ }^{19}$ The same is true in other countries. Grosmolard, head of certain penal institutions in Lyons, France, stresses the great influence that a broken home has upon juvenile delinquency. ${ }^{20}$ The Dutch criminologist Bonger reports a statistical investigation of the family background of juvenile offenders and the conclusion thereof that of the boys, $31.7 \%$ were semi-orphans; of the girls, $37.1 \%$ were semi-orphans. ${ }^{21}$

Remarriage apparently does not improve the situation much. The child often resents the presence of a foster parent in the home. He may refuse to take a stepparent's advice and moral guidance. According to Bonger's reported statistics $19.5 \%$ of delinquent boys and $35.2 \%$ of delinquent girls had either a stepfather or a stepmôther.

In evaluating statistical data as to juvenile delinquency one should not overlook the fact that not all cases reach the court. From many families no statistics are available. Consequently, the factual participation of children of divorced parents in delinquency may be even higher than we know.

\section{Custody}

When a family breaks up, through divorce or separation, a major conflict may arise between the parents over who shall have the custody of the children. Sometimes, of course, parents, already demoralized in their emotions, display an indifference to this problem. If the parents reach an agreement in or out of court as to

${ }^{17}$ Scarf, Special Disabilities in Reading and Arithmetic (April 1933) 10 Induns UnIv. Schoor of ED. BuLz. 70-84.

18 Walenstein, Character and Personality of Children from Broken Homes (1937) 82 f.

${ }^{10}$ Katherine Ienroot (1932) ro Social Forces 527.

20 "Besides material poverty, and as an auxiliary to this factor, we find the moral poverty of the home, manifested by the disorganization of the family. ... The disruption, whether private through separation of the couple, or officialized by divorce, has no less deplorable consequences for the children." Bonger, Crimtnhitity and Economic Conditions (Horton's trans. I916) 495, quoting from GrosMolaskd, Cruminalité Juvenile, 201.

${ }^{21}$ Bonger, Introduction to Criminology (Van Loo's trans. I936) $84 \mathrm{ff}$. 
custody, and if this agreement seems to be reasonable to the judge from the point of view of the welfare of the children, the question of custody is easily solved. In situations where parental agreement cannot be reached the judge has to decide, according to his discretion, which of the parents shall retain custody of the child. In doing so he is confronted with two major demands upon his attention: (a) the claims of the parents and (b) the interests of the children. The evaluation of such factors is a matter of application of legislative principles as well as of individual discretion.

\section{Claims of the Parents}

In most of the statutes of the older type which still prevail in various countries the general principle is proclaimed that the innocent party (and not the guilty one) is first of all, entitled to custody of the children. By this device the legislator seems to be seeking to punish one of the parents for breaking up the family. Therefore in awarding custody the judge may be expected to establish the guilt for bringing about a divorce. This is not always easy. Only a few codes disregard completely the problem of guilt. In this respect the attitude of Soviet Russian law is significant: in deciding questions connected with divorce the only matter that must be of interest to the judge in such cases is the interest of the child and there is no necessity of evaluating the "moral conduct" of the parents, as is emphasized in the following Resolution of the Supreme Court of the Russian Socialist Federated Soviet Republic:

"in the decision of our court, which is an organ called upon to spread among the masses revolutionary ideas, the principles of new life, and of a comradely attitude toward women, it is intolerable to use expressions which show that the court, so far from going in advance of the masses served by it, is dragging in tail of philistine moods inherited from the old regime." 22

\section{Interest of the Child}

The statutory provisions which proclaim the general principle of guilt in awarding custody of children frequently make the reservation that if the interest of the child so requires, custody may be awarded even to the guilty party or to a third party. Some laws on the subject speak exclusively in terms of the interest of the child. ${ }^{23}$ This interest being a broad and somewhat loosely defined concept, the legislators provide in some cases for certain indications as to where and how it is to be ascertained.

\section{Free Choice by the Child}

The most radical solution is to give choice to the child, himself. With which of the parents does he want to remain? But such a right is given only to children who are capable of making a free decision. In England the normal practice is to make no order in the case of children over 16 years of age; similarly, except where

${ }^{2}$ Chso, stupra note II, at 13 .

${ }^{23}$ Canndian Encyclopedic Digest, Cossol. Supp. 935 to 1938 (Ont. ed. 1938) 397. 
"essential for their welfare" minors who have reached the "age of discretion" (I4 for boys, I6 for girls) will not be compelled to return to the custody of a parent against their will. ${ }^{24}$ A somewhat similar situation prevails in Ontario. ${ }^{25}$ In Ecuador, choice is given to sons over the age of puberty. ${ }^{25^{a}}$

Age and Sex

In some laws it is implied that considerations of age and sex may be determining factors as to the interest of the child. Many codes use the conventional statement that the mother "unless for grave reasons," shall have the custody of the very small children. That is the attitude of China, ${ }^{26} \mathrm{Cuba},{ }^{27}$ Republican Spain, ${ }^{28}$ Argentina ${ }^{20}$ and Brazili ${ }^{30}$ (the two latter countries in separation cases).

This minimum age varies in different countries mostly within the limits up to three or up to seven years. As to the criterion of sex it is provided in some enactments that girls should always go to the mother and boys to the father. It seems that such a provision in particular as to girls may be justified by considerations of their specific difficulties in the adolescent period.

\section{Maintenance}

As distinguished from custody which implies the physical and moral control of the child, maintenance has purely economic aspects. However, one should not overlook the moral angle of maintenance. When family ties have been severed and the child has been given in custody to one spouse, the other spouse being obliged to provide maintenance, this obligation may create in the non-custodian parent a feeling of moral responsibility for the fate of the child. Parents who are not charged with maintenance are perhaps more apt to forget altogether about their child.

\section{Whose Obligation?}

The question arises whether the court in its final settlement is at liberty to charge both parties or only one with maintenance. If only one-there is the further query, which one? The legislative provisions which adhere to the punitive (guilt) principle in divorce settlements are inclined to charge with support only the noncustodian guilty party. That is the attitude of Brazi ${ }^{31}$ (separation cases), Netherlands, ${ }^{32}$ Alaska ("unless otherwise manifestly improper") ${ }^{33}$

There seems to be a tendency in various countries not to charge the mother with maintenance. This tendency perhaps is based upon the traditional concept

\footnotetext{
${ }^{24}$ Latey, Divorce (12th ed. 1940) 253. $\quad{ }^{25}$ Canadian Encrclopedic Digest, supra note 23.

252 Martindale-Hubbard Law Directorx (1944), Ectidor Law Digest (under title "divorce").

${ }^{28}$ China: Marc van Der VALK, op. cit. supra note $\mathrm{I}$, at $\mathrm{I13}, 120$, in notes to code articles $105 \mathrm{I}, 1055$.

${ }^{27}$ Cuba: Ley de Divorcio, May Io, 1934 (GaceTA, May Ir, 1934) arts. 23, 24.

${ }^{28}$ Spain: Ley de Divorcio, March 2, 1932 (GACETA, March 12, 1930) art. 17.

${ }^{29}$ Argentina: Codigo Crvil (r939 ed.) art. 213.

so Brazil: Codico Crvil (Clovis Bevilaqua, 6th ed. I941) art. $326 . \quad$ ax Id., art. 321.

${ }^{32}$ Netherlands: Code Civil NEERLANdais (Fr. trans., Haarebrink, Bruxelles, 1921) art. $374 g$.

${ }^{33}$ Alaska, Coxp. Laws (1933) \$3995.
} 
of the father in the stable family as the main bread-winner. Such an attitude overlooks the fact that in modern society women are participating more and more in economic life; and, in some countries, a constantly growing part of the national wealth seems to be concentrated in the hands of women. In such conditions excusing the woman, as a matter of principle, from the obligation of maintenance may not be only unjustified, but may create even harsh consequences for the other party. It may even influence unjustly the basic problem of granting custody. The following example may illustrate the situation. A poor man married a rich woman. Out of this wedlock were born two children. The father is emotionally much attached to the children and spends with them all his free time. The mother spends all her free time in night clubs with friends. Upon divorce it may occur that the judge will grant custody to the mother, only because of the traditional point of view, that a woman cannot be charged with maintenance. It is obvious that the wealth of the woman, and the reluctance of the judge to make her responsible for maintenance, deprives the father of his basic right to custody, to which he is otherwise entitled.

The mere fact that the non-custodian parent is the mother, should not preclude her from supporting her own child where her financial situation permits her to do so. Several examples from foreign laws support such an attitude. In England the mother may essentially be charged with maintenance, but apparently this provision of the law has been rarely invoked till now. ${ }^{34}$ In Russia, it is surmised that a study would show that not infrequently the mother actually is ordered to contribute to maintenance because she is economically more independent there than in other countries.

\section{The Extent of Maintenance}

The standards of maintenance either implied or stated are determined by factors such as the capacity, social and economic status, reasonable living expenses of the parents. Such seems to be the law in Ontario, ${ }^{35}$ Alberta, ${ }^{36}$ China, ${ }^{37}$ England, ${ }^{38}$ Mexico, ${ }^{39}$ Russia, ${ }^{40}$ Switzerland, ${ }^{41}$ France, ${ }^{42}$ Nicaragua. ${ }^{43}$ Some regulations are more specific. In $\mathrm{Cuba}^{44}$ and Romania, ${ }^{45}$ maintenance is limited to one-third of the economic capacity of the paying parent. In England, in fixing maintenance allowances, social rather than economic criteria seem to prevail. If the situation

34 Latey, Divorce (12th ed. 1940) 236.

s5 Canadian Encyclopedic Digest, stipra note 23.

36 Alberta, Rev. Stat. (I942) ch. I35, $\$ 3(2)$.

${ }^{37}$ China: op. cit. supra note 26 , art. 1089 .

${ }^{38}$ LaTEY, Drvorce (12th ed. I940) 237.

${ }^{30}$ Ḿ́xico: Código Crvil. (Luis Munoz, Leyes Crviles, I942) art. 287.

"Chuo, op. cit. supra note II, art. 23.

${ }^{41}$ Switzerland: Crvil Code (Eng. ed., ann. by Williams, 1925) art. 156, \$2.

${ }^{2}$ Planiol and Ripert, Traité Pratique de Droit Civil Français (ig26) 553.

${ }^{43}$ Nicaragua: Códico Crvil (3d off. ed. 193I) art. I69.

"Cuba: Ley de Divorcio, stpra note 27, art. 24g.

¿6 Roumania: Jonasco, La Famille et la Propriété, in La Vie Juridique des Peuples-Roumanie (Paris, 1933) 26r. 
justifies such a demand, maintenance may include also professional or university training. ${ }^{46}$ In Russia, a normal education must be secured by a maintenance order. ${ }^{47}$

\section{Guarantee of Payment of Maintenance Orders}

The legal enactments of various countries have adopted various solutions in order to secure the fulfillment of the maintenance order. Thus the laws of Mexico ${ }^{48}$ and Republican Spain ${ }^{49}$ provide for a lien or pledge upon the property of the defendant. The law of the Netherlands ${ }^{50}$ provides for garnishing the salary of the defendant if payments have been in default or irregular. In England the interested party may obtain a proper deed as security for such gross or annual sum as the court may deem reasonable. ${ }^{51}$ In the United States 26 states allow the court to require security; in 15 states the law may subject property of the parents to the decree or set it aside; in Io states the court may sequester property and appoint a receiver..$^{52}$

To sum up: A satisfactory guarantee of the fulfillment of maintenance orders should be obtained for the benefit of the children before the divorce is granted. If the party ordered to pay does not have any suitable property of his own, effort should be made that he provide a security by a third person.

\section{Penal Sanctions, Extradition and the Principle of Universal Repression}

Wilful non-fulfillment of maintenance orders comes very close-at least from moral, social and economic point of view-to notions of non-support and family desertion.

Most of the laws of civilized nations make provision in their penal codes for family desertion and non-support of dependent members of the family. ${ }^{53}$ The penalties and nature of the offense vary. In the United States it is treated as a misdemeanor in some states, and as a felony in other states. ${ }^{54}$ Most of the foreign countries do not distinguish between non-support of dependent children before a divorce is granted and wilful non-fulfillment of maintenance orders after divorce or separation has been granted. The feeling of the legislator is that a more lenient treatment of the second type of non-support would be unjustified. Indeed, one might make a legalistic argument that the second type of non-support should be punished even more severely, because the obligation is formulated expressis verbis.

${ }^{40}$ LATEy, Divorce (r2th ed. 1940) 237.

${ }^{47}$ Crus, op. cit. supra note II, at 13 , notes.

${ }^{48}$ Mexico: op. cit. sttpra note 39, art. 317.

${ }^{40}$ Spain: Ley de Divorcio, supra note 28, arts. I4, 33.

${ }^{50}$ Netherlands: op. cit. supra note 32 , art. $347 \mathrm{~h}$.

${ }^{n}$ LATEY, Divorce (rzth ed. 1940) 238, 773 .

22 Vernier, Axierican Family Laws (1932) 194.

t3 Poland: Polish PENAI CODE of I932 (Lemkin and MeDermott's trans., Dule Univ. 1939) art. 201, sec. I: "Whoever by maliciously evading the performance of an obligation imposed upon him by law to support a near relation, shall bring him to a state of destitution or to the necessity of accepting charity, is punishable by imprisonment up to 3 years, or by detention up to 3 years.

Sec. 2: The same penalty shall be imposed upon whoever shall commit the act specificd in scction I against any other person, if the obligation to support was decreed by final or performable judgment of a court." See also, as illustrative, Alberta, Rev. StAt. (1942) ch. 135, \$8.

${ }^{6} 4$ Vernier, American Family Iaws (1934) 60 f. 
It is submitted that to enforce these orders by treating violations of them for contempt of court (used in the United States) is inadequate. Such acts, if wilful, should be made a felony with all consequences and implications deriving from such a classification.

Deserting the family and wilful non-support have been recognized as offenses of such a serious character that they were made extraditable by treaties of various countries. United States in its international relations follows the same pattern. Treaties which the United States has entered into with some 12 foreign countries ${ }^{55}$ provide for extradition, in mutual relations between these countries and United States, for an offense called "wilful desertion or wilful non-support of minor or dependent children." The serious nature of such an offense was especially recognized by the Fifth International Conference for Unification of Penal Law held in Madrid in October 1933 in cooperation with the Fifth Committee of the League of Nations. ${ }^{56}$ The delegates of 47 participating countries have recognized that desertion of family and wilful non-support of dependent children should be treated as an international crime in the same way as traffic in women and children, forgery of money, etc. Furthermore, this conference adopted a resolution that the culprit in such a crime may be punished by a court of every signatory party if he escapes from the justice to be meted out to him by the courts of the country in which the offense was committed.

Thus in proclaiming the principle of universal repression of wilful non-support of dependent children this international conference went even further than the practice of extradition.

In the light of the foregoing considerations it would seem that countries which have not already done so should work out better facilities for extradition of persons who wilfully fail to fulfill maintenance orders for minor children and for punishment of such offenses by the courts of the place where the culprit is apprehended irrespective of the place where the offense was committed.

\section{The Subsidiary Financial Responsibilities of the State}

As the non-fulfillment of maintenance decrees became a widespread problem in many countries and states, the situation of the children involved grew ever more critical. ${ }^{57}$ The new international trends in child welfare brought about the promulgation of the principle that the State should provide for the subsistence of the child where the parents avoid their primary obligations. Such was the attitude of many international organizations and only recently the Eighth Pan-American Child Congress has reiterated this principle.58

${ }^{E E}$ United Kingdom of Great Britain and Northern Ireland, Albania, Austria, Bulgaria, Czechoslovakia, Estonia, Greece, Latvia, Lichtenstein, Lithuania, Luxembourg, Siam.

${ }^{50}$ Cinquìme Conférence Internationale pour I'Unification du Droit Pénal, Actes de in ConfERence, Madrid, 1933 (Paris, ed. A. Pedone, r935) 57-9r, 335-6.

87 ". . . cven after a favorable verdict she (the mother) remains helplessly waiting with them (the children) the payments of the maintenance order, without aid ever arriving, despite the law and the good will of justice." S. Dardo Herrera, Ex Divorcio, el Amor, los Hijos (Buenos Aires, I938) 156.

${ }^{8}$ Erghth Pan-American Chro Congress, Declaration of Opportunities for Children, 6 The ChuD 297 (U. S. Children's Bureau, 1942). 
In Sweden the law of June $18,1937,{ }^{50}$ provides that in certain cases the State should pay an advance maintenance contribution to any child up to the age of 16 years if his father fails to pay such a contribution at time fixed by a maintenance order or by a written agreement. It is expressly stated in this law that the State shall withhold such contributions when the mother lives with the child's father, because these contributions are intended to be made only in cases of divorce, separation and desertion. In the United States the Social Security Act, ${ }^{60}$ as amended on August 10, 1939, has introduced aid to dependent children who are deprived of parental support and who are living with one parent or close relative, because of the continued absence from the home of one or both parents.

Such a policy is quite justified by humanitarian and social policy reasons. However, one should not overlook the fact that the State, and, in the last analysis, the taxpayer, is thereby called upon to pay the contributions of the parent who in most of the cases disregards the law and his moral obligations.

While the children should not suffer because of the acts of a dishonest parent, society and the State should revise their heretofore too lenient attitude toward such parents. If the more effective enforcement of maintenance orders should involve additional public expense such payments would be justified because in the long run they factually may diminish the expenses of a State which makes contributions to maintenance orders in lieu of a recalcitrant parent. Consequently every jurisdiction should enact legislation providing for safeguards of the fulfillment of maintenance orders, for punishment of such parents and for more effective collaboration with other states in all matters pertaining to enforcement of maintenance orders beyond the boundary.

\section{Representation of Pubuic Interest and Child's Interest in Divorce Proceedings}

The integrity of the family being a problem of major public concern, the legislators of various countries have taken the attitude that divorce proceedings should not be left to the discretion of the judge and parties alone. The public interest in such matters is believed to call for the participation in such proceedings of the representatives of public or of appropriate private organizations and persons interested in family problems and in the welfare of the children.

In most of the European, and in many of the Latin-American countries, the public prosecutor is a participant in divorce proceedings. He makes recommendations to the judge especially in cases where children are involved. In Austria the court used to appoint for every divorce case a special "protector of the marriage ties" (Eheverbandverteidiger) ${ }^{61}$ In England ${ }^{62}$ a registrar may direct that separate

${ }^{59}$ Sweden: Law No. 383 of June 18 , I937, published in the Official Bulletin of the Swedish Ministry of Social Welfare, No. 68, October 1937.

${ }^{60} 49$ STAT. 624 (I935), 42 U. S. C. (1940 ed.) $\$ \$ 601-606$.

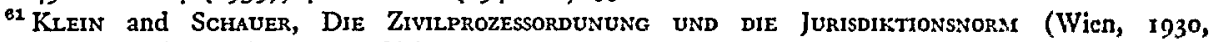
Manzsche Verlag). Anhang I.-Hofdekret v. 23, Aug. 1819, JGS, Nr. I995 Art. 17; Verordnung des Justizministeriums v. 9. De. I897, RGBI. Nr. 283 , Art. 15.

${ }^{62}$ Latey, Divorce (12th ed. 1940) 774. 
counsel for children be appointed. In Alberta (Canada) the mayor of the municipality where the child resides, or the Superintendent of Child Welfare can apply summarily to the judge for a maintenance order. ${ }^{63}$

The participation of a public prosecutor is especially effective in some countries in the post-divorce period when the enforcement of the maintenance and custody orders is involved. The public interest in divorce proceedings seems to be represented in some of the states in the United States by specially trained social workers, although their role in relation to the court does not always seem to be clearly defined.

The success of the persons representing public interest in the divorce proceedings depends on how much real authority they possess and in particular whether the judge has to listen to their recommendations by fiat of law or as a matter of grace; and also, whether the judge must treat them as equals or as subordinates. A public prosecutor has, in Europe and in Latin America, a more important part in the divorce proceedings than a social worker in the United States, who acts as a referee for the divorce judge, although the American social worker may be much better equipped professionally for participation in divorce proceedings than the European or Latin-American prosecutor.

\section{Proposed Mechanisms for Improving the Position of the Child}

The position of the child in a family crisis needs to be improved not only through a more efficient system of protection of its economic rights (enforcement of maintenance orders), but also by taking care of its moral right to live in a peaceful family, and to have this family preserved in its unity (conciliation). If, however, a divorce seems to be inevitable then the rights of the child should be most efficiently protected in the court.

It seems to the author that, in order to achieve this purpose, some of the existing institutions should be strengthened and some new institutions created.

Specifically, attention is directed to: A family adviser, conciliation procedures, a conciliation council, the family court and a family jury.

\section{Family Adviser}

The crisis of the family in modern society with all its complexities, conflicts and tensions calls for the creation in every community, and especially in those communities where family courts are located, of an office of a specially trained family adviser. Indeed the problem of the family is too important to leave to persons who would handle it as a part-time job, or who would not have the appropriate knowledge and authority to exercise enough influence upon the family and within the community. The services of the family adviser should be available not only during a period when an actual and grave crisis arises in family life, so as to threaten its disruption by divorce. But he should be ready to act as an adviser and friend of the family, whenever the interested parties call for advice and assistance in marital

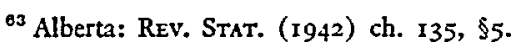


difficulties. Moreover, he should assist the interested parties in carrying out and enforcing maintenance and custody orders. Especially important would be his role as conciliator in order to prevent divorce.

When the case is actually brought before the family court for divorce the family adviser should act before the judge as representative of the public interest, with functions and position similar to those of a public prosecutor in the European and Latin-American judicial structure in divorce cases. As representative of the State for the purpose of preserving the unity of the family and the welfare of the children, the family adviser should make his recommendations to the judge. The judge should be obliged to evaluate such recommendations in his decision; and, if he disagrees with them, the reasons of such disagreement should be given. The brief of the family adviser should be handled by the judge with the same legal consequences as the brief of the counsel of every party.

The family adviser should be an official appointed by the State from among the best trained social workers, with security of tenure. In order to lend more authority to his recommendations he should be made independent from the judge in the same way as the public prosecutor is independent. The family adviser should have a deputy and a staff of assistants including doctors, psychiatrists and experts in sexual hygiene. For practical reasons the services of local clinics may be invoked. As family difficulties necessarily concern both sexes either the family adviser or his deputy should be a woman.

\section{Conciliation}

The legislation of various countries and the leading authorities in the field of family relations ${ }^{64}$ proclaim the necessity for conciliation in divorce proceedings. However in most legislation such a principle does not now mean more than the general obligation of the judge to try to reconcile the parties in every civil case before him. What is really necessary in this matter is not only the proclamation of the principle, but a special procedure and special institutions for the implementation of conciliation. One should not overlook the well-established fact that real progress in law is effectuated not so much by general principles established in substantive law as by the creation of appropriate procedural machinery.

One of the first important conciliation laws in divorce procedures was enacted in France in I886 and was incorporated in the Code Napoleon (Art. 235 and subsequent articles). According to this law one of the spouses may apply to the president of the court to summon the other spouse for conciliation before engaging in a divorce procedure. While the normal divorce procedure may take place before a justice of the peace, a conciliation procedure is administered by the highest presiding officer of the tribunal in order to create an atmosphere of more authority and stronger moral influence upon the parties. The session is not public but takes place in the private chambers of the president of the tribunal; no lawyers are ad

"Bradway, Proposed New Techniques in the Law of Divorce (1943) 28 IowA L. REv. 256. 
mitted. If a conciliation has not been effected a special record is drawn up from this session and such a document authorizes the interested parties to file a divorce suit with the court (permis de citer). The president of the tribunal may postpone the handing out of such a record to the parties and may try a further conciliation within the period of twenty days. ${ }^{65}$

This French law has, to a great extent, influenced the conciliation procedures in various countries and in some of the states of the United States.

The California Code of Civil Procedure provides for a Children's Court of Conciliation and an office of a Director of Conciliation. ${ }^{66}$ According to this law the Superior Court sits as Children's Court of Conciliation when a divorce petition is filed and when it appears that a minor child is involved whose welfare may be affected by the dissolution of the marriage. The Director of Conciliation is a commissioner appointed by the court and he acts as mediator and conciliator between the parties seeking divorce. He may, at the same time, summon other persons to his office, in order to establish the necessary facts and also in order to get their assistance in the conciliation procedure. If the attempted reconciliation fails, the parties may then file a suit for divorce at the same Children's Conciliation Court. Contrary to the French model of this law the Director of Conciliation has a lower position than the judge administering divorces. Conciliation procedures have also been introduced in Milwaukee County, Wisconsin ${ }^{67}$ New York City ${ }^{67 a}$ Rhode Island..$^{6 \mathrm{D}}$

\section{Conciliation Council}

Four essential problems are involved in a conciliation procedure. First, it is necessary to obtain all the facts of the case and to understand the real causes of the family crisis. These are sometimes so involved that the parties themselves are not completely aware of their underlying nature. Second, it is necessary to find out in the particular case how one could influence most effectively the various parties in order to bring about a reconciliation. Third, the reconciliation should be permanent or as permanent as possible. Certain planning should be done to remove the real and disrupting causes to harmony. Fourth, in some cases the reconciled spouses will need moral and other assistance in the post-reconciliation period. Such assistance should be planned at the time of the reconciliation proceedings.

Conciliation thus calls for an appropriate personnel in order that its purposes may be adequately carried out. In the writer's opinion, the office of a family adviser, together with a specially created conciliation council, could successfully carry on these functions. It is important that neither the family adviser nor the conciliation council should be subordinate to the court; they should have their own

os Planiol and RIPERT, op. cit. supra note $42,463 \mathrm{ff}$.

${ }^{\circ 6}$ Caz. Code Civ. Proc. (Deering, I94I) \$\$1730-1772.

ar Wis. Stats. (I7th ed. 1943) \$252.07.

a7a Domestic Relations Court Act of the City of New York, Laws 1933, Ch. $482 ; 66$ McKinNEY LAWS (1939) 1434 .

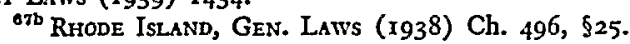


independent standing, which would increase their authority and influence upon the parties, the family court and throughout the community in general. The conciliation council might be composed of permanent members and invited members. The permanent members might be the family adviser himself as chairman, and three officers attached to his staff, e.g., a social worker, a psychiatrist and a lawyer, presumably the legal counsel to the family adviser (the assistance of the latter would be important because there may be special legal matters connected with family disputes, etc.). The invited members are: friends of the family; preferably the family doctor; the clergyman of the church to which the parties belong; and other family friends whom the family adviser shall consider as suitable because they possess an intimate knowledge of the family and they may be able to exercise their influence toward a reconciliation. Not in all cases would it be necessary for the family adviser to call in the conciliation council. As a matter of fact in certain circumstances it may be even more appropriate for the adviser to have a heart-to-heart talk alone with the parties. The procedure should be flexible and informal.

If the conciliation endeavors have failed, then the family adviser may issue a certificate stating this fact. Thereafter the parties may file a suit for divorce. However, the family adviser in his discretion should be entitled to insist upon a "coolingoff" period from three to six months. In the meantime, he may undertake further steps toward reconciliation.

In the course of the conciliation proceedings special attention should be paid to the problem of minor children. Indeed there seems to be no better way to preserve the family and save the children from the tragic fate they would have to endure as orphans of living parents. Conciliation procedure would seem also to be desirable in divorce cases of childless spouses. It should be made obligatory if minor children are involved.

\section{The Role of the Lawyer in Conciliation}

An improvement in the handling of divorce cases, in the interest of the children, is impossible without the cooperation of the lawyer. There has been a certain hesitation in some countries to encourage participation by the lawyer in divorce cases. He has been suspected of unwillingness to cooperate in conciliation. Such a distrust is implied in the above-quoted French law on Conciliation of 1886 . However, such a criticism does not seem to be completely justified. Indeed the lawyers in their private offices do a great deal more of reconciliation work than the public realizes. One should read the recent book by Madam Wei Tao Ming, a former practicing lawyer in Shanghai and wife to the Chinese Ambassador to this country. ${ }^{88}$ She describes, with great enthusiasm, the reconciliation work in divorce cases which she and her husband did in their law offices in Shanghai. The author of the present article could also cite cases, known to him, from various countries where several law offices have reconciled hundreds of divorce cases. If one would exclude the

${ }^{68}$ Wei Yu-horu (Cheng), MY Revolutionary Years (New York 1943) 147-154. 
lawyer from participation in the conciliation procedure it would not preclude the parties from seeking his advice in his own offices. In cooperating with the family adviser and conciliation council the lawyer of the parties would become a part of a new interprofessional movement in handling family disputes. Moreover not only should the lawyer who handles divorce cases become interested in the conciliation practice, but the Bar Associations should be invited to cooperate. In every local Bar Association there should be created a committee on family conciliation which should encourage conciliation practice among lawyers. In particular it should be made an obligation of every lawyer handling a divorce case to file a report with the conciliation committee of the Bar Association as to his role, his endeavors and what he has been able to accomplish.

\section{The Family Court}

Divorce, neglect of children, juvenile criminality, desertion and non-support all represent different variations of the same pathological phenomenon in the life of the family. If the parents are in irreconcilable conflict, if they are neglecting the children, if the father deserts the family and leaves it without support, it means that something is wrong in the moral structure of the given family. These problems seem to be mutually interrelated. It is only reasonable to urge that they should be treated in one and the same court which would be called "Family Court." Such a court should also try cases of adoption, because that too is a typical problem connected with the life of the family. By centralizing different family cases in one court it is possible to obtain a higher degree of technical specialization on the part of the judge and also on the part of the court personnel. Moreover the services and experiences of various private institutions and agencies acting now on behalf of the court in cases connected with family life could be centralized and better utilized in the service of the common cause. All this would contribute to the improvement of the standards of justice in family cases and would also increase public confidence in the court.

\section{The Family Jury}

If one agrees that the most serious of all divorce cases, from the point of view of public interest, are those in which children are involved, one may also agree that the trial of such cases should be handled with special care and a consciousness of the gravity of the situation. Generally speaking every divorce case, in which minor children are involved, represents a conflict of three spheres of interests: the interest of each contending spouse (at least one of whom is seeking to disrupt the family) and the interests of the children (who are most vitally concerned in maintaining the unity of the family, as a source of their moral and physical existence). It is true, for most of the cases, that at least one of the spouses is concerned with the special rights of the child and feels special obligations toward the child (custody and maintenance). But from the point of view of the child these special rights and obligations are of secondary importance. The maintenance of the family unity 

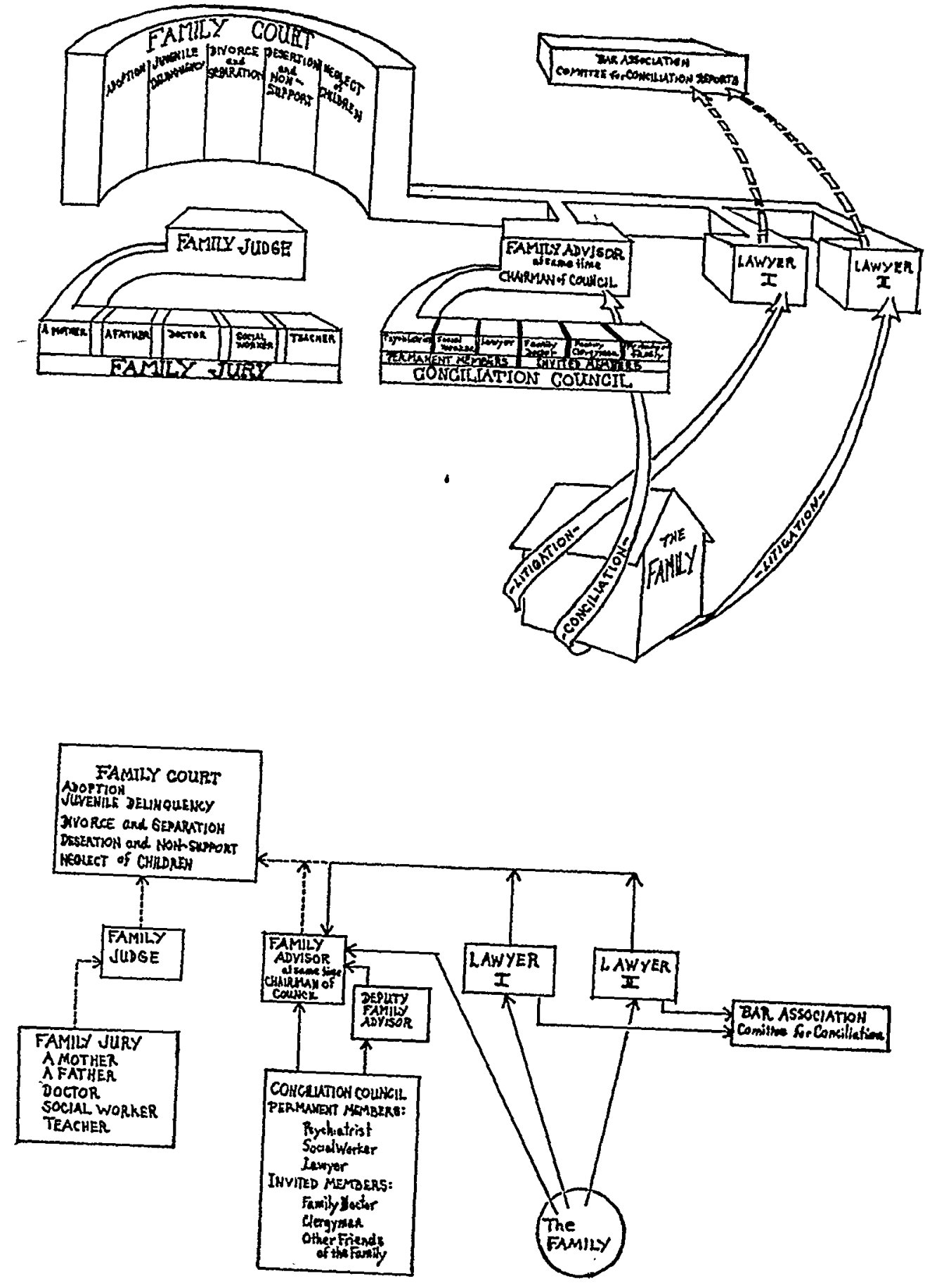

COURSE of CASE WHEY CONCHINTION FNLS

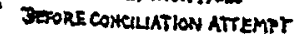


as a source of security remains objectively speaking the main interest of the child. These very serious cases should be in the writer's opinion handled by a jury.

Since the constitutional provisions of many countries grant to the adult citizen the right that his case should be tried by a jury, there is no reason whatsoever to deny a similar right to the child. To the contrary there are even more reasons for granting the right of trial by jury to children than to adults, because the children are the weakest among the citizens and need more protection of their rights. In a time when a great many humanitarian principles are being proclaimed for the benefit of the child one should not deny him the most human and vitally important of his rights, to love, security and happiness in the family circle. Every child should have the right to trial by jury of a case where the unity of his family is at stake.

While one should recognize the importance of a jury trial in divorce cases where minor children are involved, one should not overlook the fact that the actual composition of that jury if selected as in ordinary civil and criminal cases, would not necessarily be adequate to decide the fate of minor children. In divorce cases it seems desirable that a jury of specialists or of persons familiar and sympathetic with the problems of the particular family should be instituted. The qualification of fairness is not enough. A special knowledge and understanding of the problems of the child, and a desire to protect him are very important. If a divorce is indicated in the case, then the jury would be expected to cooperate with the judge, in the decisions as to custody and maintenance. In this respect the divorce proceedings would be closer to a kind of "protective" than "distributive" justice. The protective function of justice at present apparently does not function efficiently enough in those very cases where it is most needed, namely, when children lose their parentsupporter. ${ }^{69}$

The family jury should not be composed of a great many persons but rather of a few competent persons. If one should decide to limit the number to five persons they should be: a social worker, specialist in family and child problems; a doctorpsychiatrist; a teacher; and two other lay persons, who possess experience in family life. A respectable father and a respectable mother in the community would be useful. A jury so composed could be selected by ballot from five lists; each representing one of the above groups. There may be, in some communities, a difficulty in securing a sufficient number of specialists in psychiatry; but this difficulty may be overcome by introducing into the jury a general practitioner of medicine.

The idea of a specialized jury is not new. In 1933, Mariano d'Amelio, President of the Supreme Court of Italy, proposed to use a technical jury in certain cases requiring technical knowledge. ${ }^{70}$ Technical advisers to judges have been introduced in several European countries, among them Poland. England in certain cases uses

\footnotetext{
${ }^{00}$ For example, in Connecticut in a total of 1,808 cases of divorce in which minor children were involved, only in 318 cases was alimony (with, presumably, children's maintenance included) decreed. Clark \& Schulman, Law Administration in Connecticut (1937) 152, tables.

${ }^{70}$ Troisième Congrès Internattonal de Droit Pénal, Actes du Congrès, Palermo, 1933 (Roma, Istituto Poligráfico dello Stato, 1935) 313-477, 537-631, including papers by Saldaña, Perreau, Glaser, Simon, Chauvau, Carnevale, and this writer.
} 
lay-judges. In judicial theory and practice the contributions of laymen to the decision of cases has proven very useful, not only by helping the judge to understand complicated technical matters, but also by introducing new ideas into the decisions of the court. Some judges of a conservative type might not otherwise have occasion to consider them.

In the family court a family jury would not only safeguard the interests of the child and the essential unity of the family but would enrich the court proceedings by a new and a more realistic and scientific approach to family problems. In certain countries social workers have had difficulties in impressing such views upon the law because of a certain reserve on the part of the judges. However, the proposed composition of the family jury does not overlook the necessity of counterbalancing scientific ideas by a practical approach which may be found in the persons of the judge and of the two or three lay members of the jury (a father, a mother, a teacher).

The family jury would also constitute a safeguard against the political element which exists in some countries where the judge is not appointed to his office but is elected.

\section{Training of Persons Concerned with Family Relations}

Persons concerned with family cases should be especially trained in order to be able to carry out their activities more effectively. In order to understand the complexity of divorce cases, especially of those in which minor children are involved, a deeper psychological and sociological approach is necessary. There may be diffi-. culties in creating a sympathetic understanding between a lawyer and a sociologist in a family case. It may be argued that the lawyer is primarily concerned with the delimitation of rights among individual members of the family whereas a social worker is first of all concerned with the functional side of the family and its sociological and psychological implications. A basis for an understanding between these two essential elements in handling family cases must be found through some sort of training by each group in the field of the other. The lawyer should be trained more in sociology, ${ }^{71}$ and the social worker more in law. This can be done through certain adjustments in the university curricula. In the requirements for pre-legal training one should include sociology, psychology, and criminology. Moreover in the law schools, the courses given in family law, and criminal law should be orientated more and more so as to include the sociological aspects of the family and the criminological aspects of crime in general and of juvenile delinquency in particular. On the other hand the curriculum of the schools for social workers should include family law, criminal law, and public administrative law, the latter being important for the activities of the social worker in time as society becomes more interdependent through urbanistic and industrial evolution which finds expression more and more in government and state regulation.

${ }^{71}$ A more specific training of the lawyer (and future judge) for family relations practice is indicated also by the great number of divorce cases. For example: in the State of Connecticut in 1942 morc than one-third of the civil cases tried or otherwise disposed were divorce cases. (Statistical data provided by courtesy of the Children's Bureau in Washington, D. C.) 